Check for updates

Cite this: RSC Adv., 2017, 7, 18421

\section{Heavy-metal pollution alters dissolved organic matter released by bloom-forming Microcystis aeruginosa}

\begin{abstract}
Haiming Wu, ${ }^{a}$ Li Lin, $^{\mathrm{b}}$ Guangzhu Shen ${ }^{\mathrm{a}}$ and Ming Li (D) *ac
The risk of heavy metals to aquatic ecosystems has been paid much attention worldwide in recent years, however, the knowledge on effects of heavy metals on dissolved organic matter (DOM) released by Microcystis was quite poor, especially in eutrophic lakes. The aim of this study is to investigate effects of heavy metals on DOC release of Microcystis using EEM-PAFAFAC analysis. Microcystis aeruginosa was batch cultured for 18 days in BG-11 medium treated with a range of concentrations of $\mathrm{Cu}^{2+}(0.02,0.05$, 0.10 and $\left.0.25 \mathrm{mg} \mathrm{L}^{-1}\right)$ and $\mathrm{Zn}^{2+}\left(0.10,0.20,0.50\right.$ and $\left.1.00 \mathrm{mg} \mathrm{L}^{-1}\right)$, to investigate the effects of heavy metals on DOM release of Microcystis. The cultures without addition of $\mathrm{Cu}^{2+}$ or $\mathrm{Zn}^{2+}$ were set as controls. Cell density in the treatment of $0.25 \mathrm{mg} \mathrm{L}^{-1} \mathrm{Cu}^{2+}$ was $25 \%$ less than that in the control, but addition of $0.25 \mathrm{mg} \mathrm{L}^{-1} \mathrm{Zn}^{2+}$ had little effect on Microcystis growth. Moderate levels of $\mathrm{Cu}^{2+}(0.05$ and $\left.0.10 \mathrm{mg} \mathrm{L}^{-1}\right)$ and high level of $\mathrm{Zn}^{2+}\left(1.00 \mathrm{mg} \mathrm{L}^{-1}\right)$ stimulated DOC production of $M$. aeruginosa on day 10; moderate levels of $\mathrm{Zn}^{2+}\left(0.10-0.50 \mathrm{mg} \mathrm{L}^{-1}\right)$ stimulated DOC production on day 18 compared to the control. Four components of DOM: two humic-like components (C1 and C3) and two protein-like components ( $\mathrm{C} 2$ and $\mathrm{C} 4$ ), were identified by fluorescence excitation - emission matrix spectroscopy combined with parallel factors (EEM-PAFAFAC) analysis. The fluorescence intensity of the four components increased when Microcystis was treated with moderate level of $\mathrm{Cu}^{2+}(0.05$ and $0.10 \mathrm{mg}$ $\mathrm{L}^{-1}$ ) on day 10. In addition, the composition of DOM produced by Microcystis was not affected by heavy metals. Our results suggested that Microcystis increased DOM production in logarithmic phase by altering cellular secretion, but large biomass was the effective measure for $M$. aeruginosa to reduce toxicity of heavy metals in the stationary phase.
\end{abstract}

Received 11th January 2017 Accepted 13th March 2017 DOI: 10.1039/c7ra00414a

rsc.li/rsc-advances
Cyanobacterial bloom in lakes and reservoirs is another environmental issue resulting from anthropogenic activities. ${ }^{5}$ This phenomenon causes serious environmental problems, such as oxygen depletion, unpleasant odors, and toxin production. ${ }^{6}$ However, bloom-forming cyanobacteria, including the most widely distributed example, Microcystis, have been reported as carbon sources for zooplankton in eutrophic lakes. ${ }^{7}$ Microcystis also releases dissolved organic matter (DOM) into water, including polysaccharides and amino acids. ${ }^{8}$ DOM is an important energy source for heterotrophic bacteria, which vary dramatically in response to varying environments., ${ }^{\mathbf{9 1 0}}$ Therefore, the variation in DOM released by Microcystis under different environmental conditions should be well understood.

The concentration of dissolved organic carbon (DOC) has been shown to increase with decreasing nitrate in a eutrophic lake (Lake Taihu, China) with Microcystis blooms. ${ }^{10}$ Furthermore, Yang and Kong ${ }^{11}$ reported that the concentrations of extracellular polysaccharides (EPS) and the main component of DOM released by Microcystis were higher when treated with a lower nutrient concentration. These results demonstrated that DOM concentration is negatively correlated with nutrient level. The effects of temperature and light intensity on the EPS of
${ }^{a}$ College of Resources and Environment, Northwest A\&F University, Yangling 712100 , PR China. E-mail: lileaf@163.com

${ }^{b}$ Department of Water Environment Research, Changjiang River Scientific Research Institute, Wuhan 430010, P. R. China

${ }^{\prime}$ Key Laboratory of Plant Nutrition and the Agri-environment in Northwest China, Ministry of Agriculture, PR China 
Microcystis have also been well studied..$^{12} \mathrm{Bi}$ et $a l .{ }^{13}$ indicated that increasing $\mathrm{Pb}$ concentration promoted EPS production in Microcystis. Herzi et al. ${ }^{14}$ showed that the DOC concentration of Alexandrium catenella varied greatly when exposed to different concentrations of $\mathrm{Pb}$ and $\mathrm{Zn}$. Therefore, it could be deduced that heavy metals can affect DOM production by Microcystis. Accordingly, heavy metal pollution can affect DOM dynamics in aquatic ecosystems by influencing DOM release from Microcystis, especially in eutrophic lakes where Microcystis blooms occur frequently. However, the effects of heavy metals on DOM release by Microcystis are poorly understood, and should be investigated with regard to quantity and quality.

Fluorescence excitation-emission matrix spectroscopy combined with parallel factor analysis (EEM-PAFAFAC) is a rapid and effective method for identifying the composition of complex organic matter, and has been widely applied to characterize DOC in lakes and algal EPS. ${ }^{15-17} \mathrm{Xu}$ et $a .^{18}$ analyzed extracellular polymeric substances from Microcystis by EEMPARAFAC and successfully determined four components belonging to protein-like and humic-like substances. Additionally, Herzi et al. ${ }^{\mathbf{1 4}}$ analyzed the DOM released by Alexandrium catenella exposed to heavy metals using the same method.

The aim of this study is to investigate the effects of heavy metals on DOC release in Microcystis using EEM-PAFAFAC analysis. Microcystis aeruginosa, a common bloom-forming Microcystis species distributed worldwide, was chosen as the test organism. $\mathrm{Cu}$ and $\mathrm{Zn}$ were chosen as the test heavy metals because copper sulfate is often added into lakes as an agent to remove Microcystis ${ }^{\mathbf{1 9}}$ and the $\mathrm{Zn}$ concentration is always higher than those of other heavy metals in lakes and reservoirs. ${ }^{20}$ Furthermore, $\mathrm{Cu}$ and $\mathrm{Zn}$ are necessary trace elements for photosynthesis. $^{21}$ The results of this work increase understanding of the effects of heavy metals on energy flows and carbon cycles in aquatic ecosystems.

\section{Materials and methods}

\subsection{Organisms}

M. aeruginosa (FACHB 469) was provided by the Freshwater Algae Culture Collection of the Institute of Hydrobiology, Chinese Academy of Sciences. This strain was cultivated axenically in BG-11 medium for more than three months and existed as single cells before experiments.

\subsection{Culture conditions}

The alga was batch cultured in BG-11 medium $(120 \mathrm{~mL})$ in a 250 $\mathrm{mL}$ conical flask with varying $\mathrm{Cu}^{2+}$ and $\mathrm{Zn}^{2+}$ concentrations. The concentrations were adjusted to $0,0.02,0.05,0.10$, and $0.25 \mathrm{mg}$ $\mathrm{L}^{-1} \mathrm{Cu}^{2+}$ and $0,0.10,0.20,0.50$, and $1.00 \mathrm{mg} \mathrm{L}^{-1} \mathrm{Zn}^{2+}$ using $\mathrm{CuCl}_{2}\left(5 \mathrm{mg} \mathrm{L}{ }^{-1}\right)$ and $\mathrm{ZnCl}_{2}\left(10 \mathrm{mg} \mathrm{L}^{-1}\right)$ solutions, respectively. Different $\mathrm{Cu}^{2+}$ and $\mathrm{Zn}^{2+}$ concentration ranges were selected because $\mathrm{Cu}^{2+}$ was more toxic than $\mathrm{Zn}^{2+}$ to Microcystis. ${ }^{22}$ Concentrations of $0 \mathrm{mg} \mathrm{L^{-1 }}$ were used as the control. Six replicates were carried out for each treatment. All samples were cultured at $25{ }^{\circ} \mathrm{C}$ in a light-dark cycle (12 hours each) using 50 $\mu \mathrm{mol}$ per photons per $\mathrm{m}^{2}$ per $\mathrm{s}$. The culture experiment was performed for 18 days. The flasks were shaken two or three times daily by hand to prevent cells from adhering to the inner flask walls.

\subsection{Culture enumeration}

The cell density of $M$. aeruginosa was measured every two days by counting cells in a hemocytometer three times under an optical microscope (Olympus CX31, Olympus Corporation) at $400 \times$ magnification. If the three counts differed by less than $10 \%$, the average value was calculated as the final cell density. Otherwise, additional counting was carried out.

\subsection{Analysis of DOM and DOC}

Samples were collected twice, on days 10 and 18, as three replicates. The first collection represented the logarithmic phase, while the second represented the stationary phase. The algal sample was centrifuged at $16000 \times g$ for $10 \mathrm{~min}$ and the supernatants were then filtered through a membrane with 0.45 $\mu \mathrm{m}$ pore size. The filtrate was used for the analysis of DOC concentration and fluorescence EEM spectra. DOC concentration was analyzed using a total organic carbon analyzer (TOC-L CPN, Shimadzu, Japan). Fluorescence EEM spectra were measured using a fluorescence spectrometer (F97 Pro, Lengguang Tech., China) in scan mode with a xenon lamp (700 V) at room temperature. All cuvettes were rinsed with $5 \% \mathrm{HNO}_{3}$ solution before analysis. The excitation (Ex) wavelengths were 200-450 $\mu \mathrm{m}$ with a step length of $5 \mathrm{~nm}$, while the emission (Em) wavelengths were $250-500 \mu \mathrm{m}$ with step length of $2 \mathrm{~nm}$. The scan speed was set at $6000 \mathrm{~nm} \min ^{-1}$.

\subsection{Data analysis}

All data were presented as mean \pm standard deviation. PARAFAC modeling was executed in MATLAB 7.0 software (Mathworks, Natick, MA) using the DOMFluor toolbox. ${ }^{23}$ There was no outlier sample in the leverage comparison. Residual and splithalf analyses were used to determine the correct numbers of components. Analysis of variance (ANOVA) was conducted to analyze the differences among different treatments using Tukey's post hoc test with SPSS 10.0 software.

\section{Results and discussion}

\subsection{Growth of $M$. aeruginosa}

The cell density of $M$. aeruginosa increased rapidly from day 2 to day 14, after which the growth slowed gradually (Fig. 1). The cell density in the $0.25 \mathrm{mg} \mathrm{L}^{-1} \mathrm{Cu}^{2+}$ treatment was $25 \%$ lower than that in the control throughout incubation. M. aeruginosa growth in the 0.02 and $0.05 \mathrm{mg} \mathrm{L}^{-1} \mathrm{Cu}^{2+}$ treatments was similar to that of the control. Cell density in the $0.10 \mathrm{mg} \mathrm{L}^{-1} \mathrm{Cu}^{2+}$ treatment $(3.8 \times$ $10^{7}$ cells per $\left.\mathrm{mL}\right)$ was slightly lower than that of the control $(3.9 \times$ $10^{7}$ cells per $\mathrm{mL}$ ). The maximum cell densities were $3.8,4.1,4.1$, 3.9 , and $3.7 \times 10^{7}$ cells per $\mathrm{mL}$, respectively, in the control and $0.10,0.20,0.50$, and $1.00 \mathrm{mg} \mathrm{L}^{-1} \mathrm{Zn}^{2+}$ treatments, respectively.

Tsai $^{24}$ reported that the minimum amount of $\mathrm{Cu}^{2+}$ required to inhibit $M$. aeruginosa growth was $0.16 \mathrm{mg} \mathrm{L}^{-1}$. Wu et al. ${ }^{25}$ indicated that $0.25 \mathrm{mg} \mathrm{L}^{-1} \mathrm{Cu}^{2+}$ significantly inhibited 


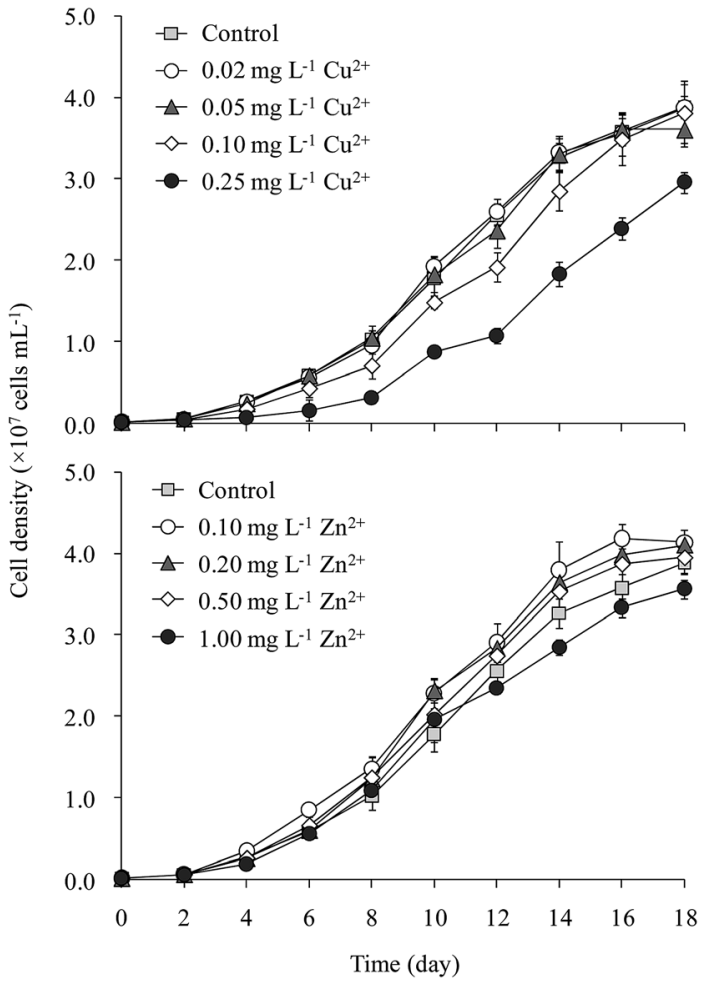

Fig. 1 Growth curves of $M$. aeruginosa at varying $\mathrm{Cu}^{2+}$ and $\mathrm{Zn}^{2+}$ concentrations.

Microcystis growth. Deng et al. ${ }^{26}$ showed that $0.10 \mathrm{mg} \mathrm{L}^{-1} \mathrm{Cu}^{2+}$ significantly decreased the Chl- $a$ content in $M$. aeruginosa. Polyak et al. ${ }^{27}$ demonstrated that $0.25 \mathrm{mg} \mathrm{L}{ }^{-1} \mathrm{Zn}^{2+}$ inhibited $M$. aeruginosa growth. Our results matched with the toxicities of $\mathrm{Cu}^{2+}$ and $\mathrm{Zn}^{2+}$ reported elsewhere.

\subsection{DOC concentrations}

DOC concentrations in the control were 74 and $120 \mathrm{mg} \mathrm{L}^{-1}$ on days 10 and 18, respectively (Fig. 2). On day 10, the DOC concentrations in the 0.05 and $0.10 \mathrm{mg} \mathrm{L}^{-1} \mathrm{Cu}^{2+}$ and $1 \mathrm{mg} \mathrm{L}^{-1}$ $\mathrm{Zn}^{2+}$ treatments were greater than that of the control. The maximum value of approximately $98 \mathrm{mg} \mathrm{L}^{-1}$ appeared in the $1 \mathrm{mg} \mathrm{L}^{-1} \mathrm{Zn}^{2+}$ treatment. On day 18, the DOC concentrations in all $\mathrm{Zn}^{2+}$ treatments were significantly higher than that of the control, except for that of the highest $\mathrm{Zn}^{2+}$ treatment. Unexpectedly, the DOC concentration in the sample treated with the highest level of $\mathrm{Cu}^{2+}$ decreased to $100 \mathrm{mg} \mathrm{L}{ }^{-1}$, while samples treated with moderate levels of $\mathrm{Cu}^{2+}$ showed no obvious differences compared with the control. Reports on the effects of heavy metals on DOC concentration in Microcystis are rare. Bi et $a l .{ }^{13}$ reported that $\mathrm{Pb}$ stimulated the production of extracellular polysaccharide (EPS) in Microcystis. Herzi et al. ${ }^{\mathbf{1 4}}$ indicated that the DOM released by A. catenella was promoted by $0.78 \mathrm{mg}$ $\mathrm{L}^{-1} \mathrm{Zn}^{2+}$, with the results similar to ours obtained from $M$. aeruginosa in this study. These results indicated that heavy metals may promote DOC production in Microcystis.

The cellular DOC content is shown in Fig. 3. In general, the cellular DOC content on day 10 was larger than that on day 18.

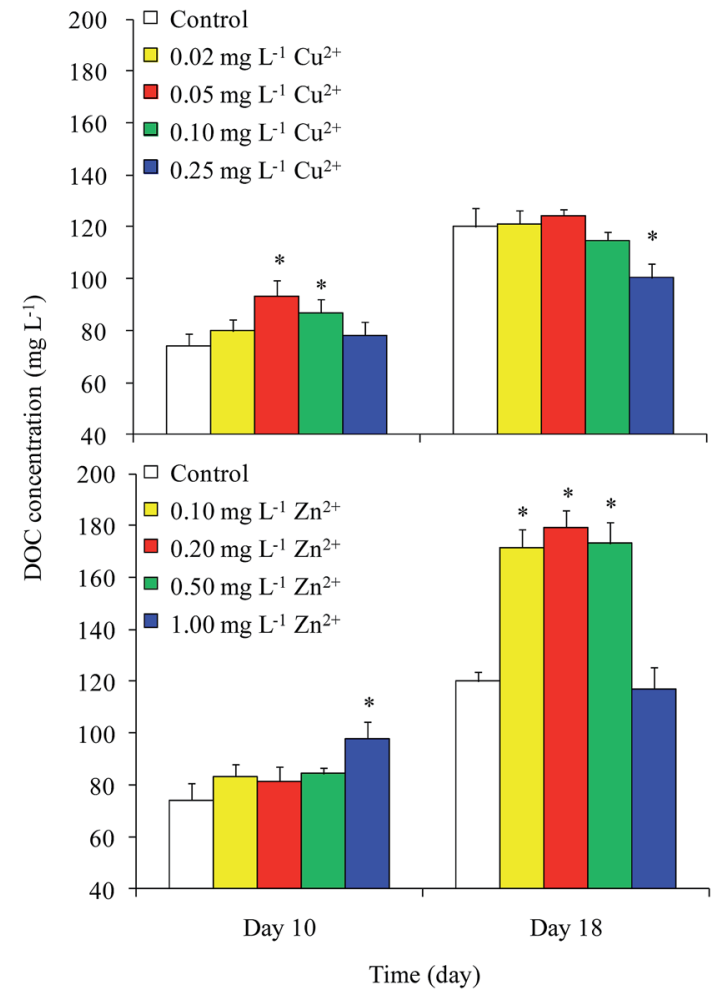

Fig. 2 DOC concentrations in culture medium at varying $\mathrm{Cu}^{2+}$ and $\mathrm{Zn}^{2+}$ concentrations on days 10 and 18 . *Indicates values of each component in the treatment that were significantly different from that in the control $(p<0.05)$.

The cellular DOC content increased with increasing $\mathrm{Cu}^{2+}$ concentration on day 10 , but differences among different $\mathrm{Cu}^{2+}$ treatments were not significant on day 18. $\mathrm{Zn}^{2+}$ addition had little effect on the cellular DOC content on day 10, except in the case of $1 \mathrm{mg} \mathrm{L}^{-1} \mathrm{Zn}^{2+}$ treatment. However, the production of cellular DOC content was promoted when treated with moderate levels of $\mathrm{Zn}^{2+}$.

The DOC concentrations in culture medium exposed to different levels of $\mathrm{Cu}^{2+}$ on day 18 were found to be significantly lower than those in the medium amended with different levels of $\mathrm{Zn}^{2+}$. Although both $\mathrm{Cu}$ and $\mathrm{Zn}$ are necessary trace elements for photosynthesis, the $\mathrm{Zn}$ content $\left(15-50 \mathrm{mg} \mathrm{kg}{ }^{-1}\right.$ dry weight) in plants is always higher than that of $\mathrm{Cu}\left(1-20 \mathrm{mg} \mathrm{kg}^{-1}\right.$ dry weight). ${ }^{21}$ In the current study, the growth and cellular DOC content of Microcystis on day 18 were significantly promoted when treated with moderate levels of $\mathrm{Zn}^{2+}$, but inhibited when treated with $\mathrm{Cu}^{2+}$. This result implied that Microcystis photosynthesis was promoted when treated with moderate level of $\mathrm{Zn}^{2+}$, causing the DOC concentration to increase.

\subsection{Composition of EEM spectra}

All fluorescence EEM spectra of DOM were successfully decomposed into a four-component model based on residual and split-half analyses. The contours and Ex/Em loadings of the four components are shown in Fig. 4. The first component (C1) gave a peak at $\lambda_{\mathrm{Ex} / \mathrm{Em}}=355 / 458 \mathrm{~nm}$. This component was 


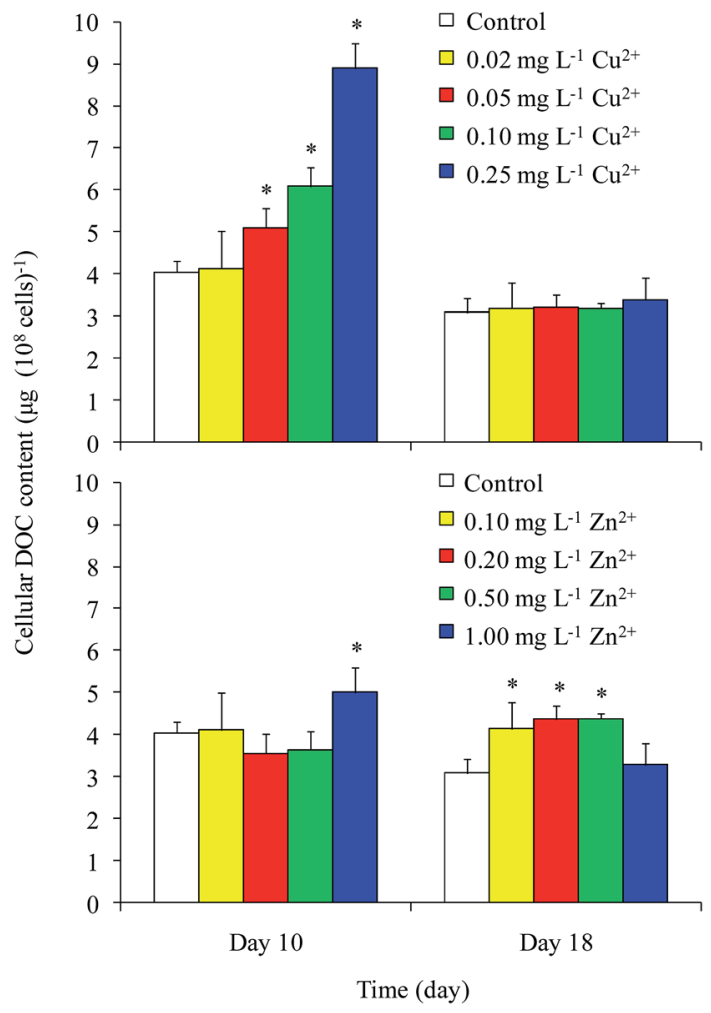

Fig. 3 Cellular DOC concentrations released by $M$. aeruginosa at varying $\mathrm{Cu}^{2+}$ and $\mathrm{Zn}^{2+}$ concentrations on days 10 and 18 . *Indicates values of each component in the treatment that were significantly different from that in the control $(p<0.05)$.

a humic acid-like compound ${ }^{28}$ also described in Region $\mathrm{V}$ by Chen et $a l .{ }^{29}$ The second component (C2) gave maximum intensities at an excitation wavelength of $235 \mathrm{~nm}$ and centered between emission wavelengths of 250 and $400 \mathrm{~nm}$. This component was identified as an aromatic protein-like compound. ${ }^{29-31}$ The third component (C3) gave two peaks $\left(\lambda_{\mathrm{Ex} /}\right.$
$\mathrm{Em}=280 / 474 \mathrm{~nm}$ and $\lambda_{\mathrm{Ex} / \mathrm{Em}}=415 / 474 \mathrm{~nm}$ ) and was defined as a UVC humic acid-like compound with a high molecular weight. $^{30,32,33}$ The last component (C4) gave a peak at $\lambda_{\mathrm{Ex} / \mathrm{Em}}=$ $285 / 358 \mathrm{~nm}$ and was defined as a protein-like compound containing tryptophan. ${ }^{18,29,34}$

Therefore, the four components identified from the fluorescence spectra were two humic-like components (C1 and C3) and two protein-like components (C2 and $\mathrm{C} 4)$. Xu et al. ${ }^{18}$ identified three protein-like compounds and a humic-like compound in the EPS of Microcystis. Aoki et al. ${ }^{35}$ found a fulvic acid-like compound, a protein-like compound, and an unknown compound in the DOM of M. aeruginosa. Yang et al. ${ }^{36}$ distinguished a tryptophan-like component and two humic acid-like compounds. The wavelength coverage of excitation and emission in the current study was much wider than previous studies, resulting in more humic acid-like components being identified.

\subsection{Variations in fluorescence contributions}

The fluorescence intensity of all four components in the DOM had increased by day 10 when treated with moderate levels of $\mathrm{Cu}^{2+}\left(0.05\right.$ and $\left.0.10 \mathrm{mg} \mathrm{L}^{-1}\right)$ (Fig. 5). However, $\mathrm{Zn}^{2+}$ had only a small effect on fluorescence intensity. Nevertheless, the fluorescence intensity of $\mathrm{C} 1$ increased when treated with $0.10 \mathrm{mg}$ $\mathrm{L}^{-1} \mathrm{Cu}^{2+}$ and $0.50 \mathrm{mg} \mathrm{L}^{-1} \mathrm{Zn}^{2+}$. The results in the stationary phase were completely different than in the logarithmic phase. For $\mathrm{Cu}^{2+}$ treatments, no significant difference was observed between the fluorescence intensities of different treatments and the control, except that the values of $\mathrm{C} 3$ and $\mathrm{C} 4$ treated with $0.02 \mathrm{mg} \mathrm{L}^{-1} \mathrm{Cu}^{2+}$ were significantly higher than those of the control. Additionally, the fluorescence intensities of C1, C3, and $\mathrm{C} 4$ in the DOM improved when treated with moderate levels of $\mathrm{Zn}^{2+}\left(0.10-0.50 \mathrm{mg} \mathrm{L}^{-1}\right)$.

The relationships among the fluorescence intensities of different components, cell densities, and DOC concentrations
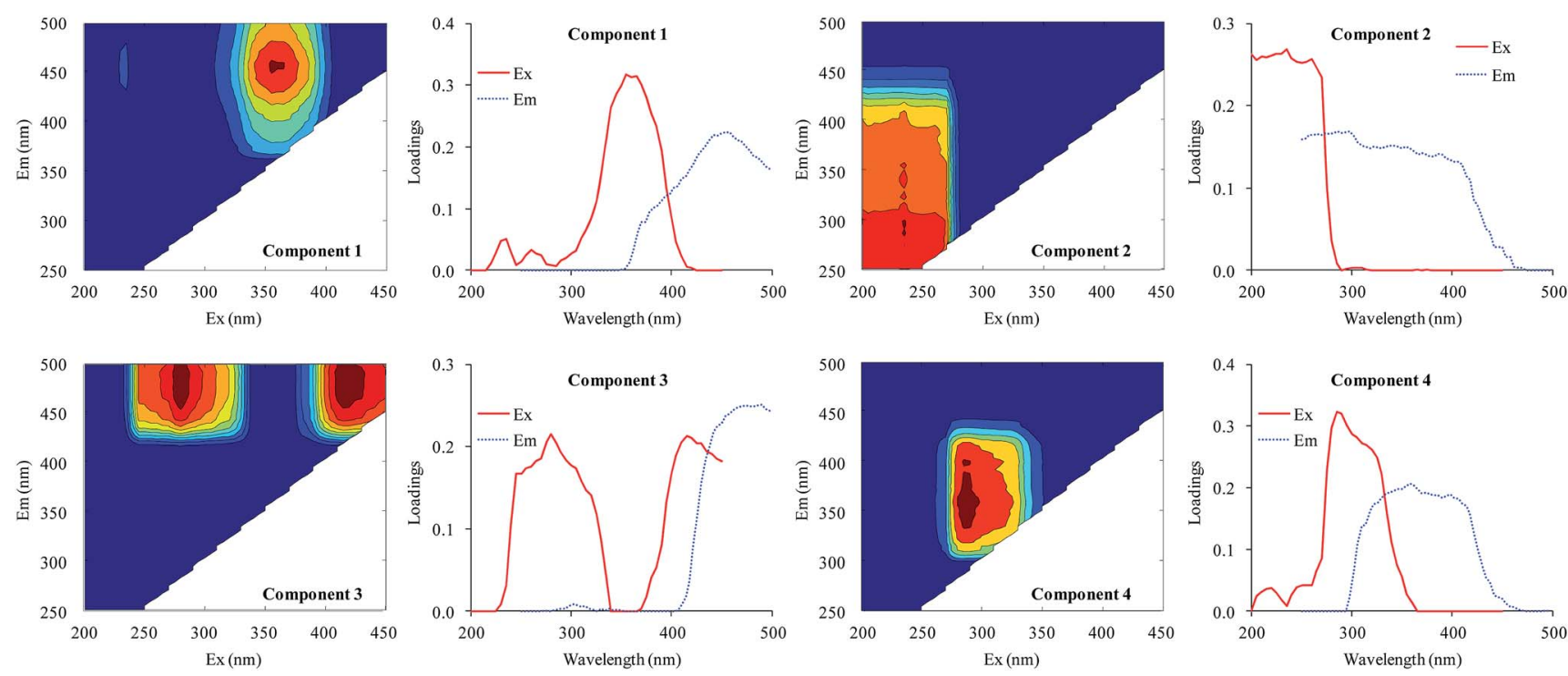

Fig. 4 EEM contours, and excitation and emission loadings of the four components identified by EEM-PARAFAC analysis. 

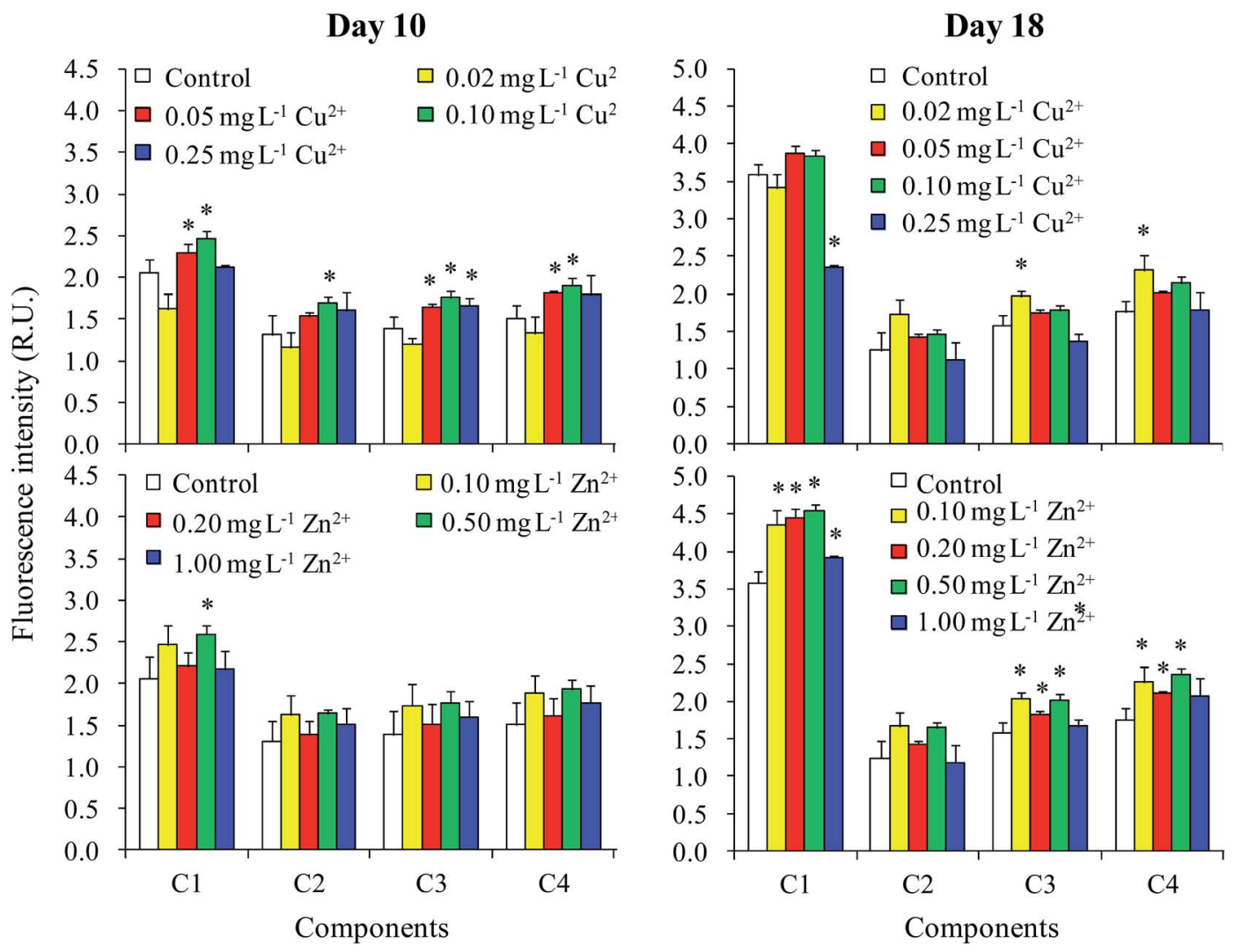

Fig. 5 Fluorescence intensities of the four components in the DOM of M. aeruginosa on days 10 and 18 . *Indicates values of each component in the treatment that were significantly different from that in the control $(p<0.05)$.

in the logarithmic phase (day 10) and stationary phase (day 18) are shown in Tables 1 and 2, respectively. On day 10, the DOC concentration was neither significantly related to the fluorescence intensities of all components, nor significantly related to cell density (Table 1). Furthermore, we found that there was no significant difference in the percentage of the four components calculated from their fluorescence intensities among the different treatments on day 10 (data not shown). These results showed that the increase in fluorescence intensity of the four components on day 10 was due to increased DOC production, but with no change in DOM composition. Moreover, the DOC concentration was not correlated with cell density on day 10 , indicating that the increase in DOC concentration induced by the addition of $\mathrm{Cu}^{2+}$ and $\mathrm{Zn}^{2+}$ (Fig. 2) was not caused by the influence of heavy metals on the biomass of $M$. aeruginosa, but by the variation in cellular secretion of DOM during the logarithmic phase (Fig. 3).

Although DOC concentrations of the cell and the culture medium treated with moderate levels of $\mathrm{Zn}^{2+}$ were greater than that in the control sample on day 18 (Fig. 2 and 3), the cellular DOC content showed no obvious variations on day 18 under treatment with varying concentrations of $\mathrm{Cu}^{2+}$. Moreover, the DOC concentration was significantly correlated with cell density on day 18 (Table 2). Therefore, it was deduced that the increase

Table 1 Pearson correlation among fluorescence intensities of different components, cell densities, and DOC concentrations in the logarithmic phase (day 10). Data were obtained from both $\mathrm{Cu}^{2+}$ and $\mathrm{Zn}^{2+}$ treatments $^{a}$

\begin{tabular}{llllllll}
\hline & Cell density & DOC & Total & C1 & C2 & C3 & C4 \\
\hline Cell density & 1.000 & & & & & & \\
DOC & 0.315 & 1.000 & & & & & \\
Total & 0.291 & 0.461 & 1.000 & & & \\
C1 & 0.479 & 0.359 & $0.961^{* *}$ & 1.000 & & \\
C2 & 0.118 & 0.465 & $0.978^{* *}$ & $0.889^{* *}$ & 1.000 & & \\
C3 & 0.227 & 0.483 & $0.995^{* *}$ & $0.931^{* *}$ & $0.989^{* *}$ & 1.000 & \\
C4 & 0.222 & 0.537 & $0.990^{* *}$ & $0.918^{* *}$ & $0.987^{* *}$ & $0.996^{* *}$ & 1.000
\end{tabular}

${ }^{a}$ Total indicates total fluorescence intensity. *Correlation is significant at the 0.05 level (two-tailed); **correlation is significant at the 0.01 level (two-tailed). 
Table 2 Pearson correlation among fluorescence intensities of different components, cell densities, and DOC concentrations in the stationary phase (day 18). Data were obtained from both $\mathrm{Cu}^{2+}$ and $\mathrm{Zn}^{2+}$ treatments ${ }^{a}$

\begin{tabular}{|c|c|c|c|c|c|c|c|}
\hline & Cell density & DOC & Total & $\mathrm{C} 1$ & $\mathrm{C} 2$ & C3 & $\mathrm{C} 4$ \\
\hline Cell density & 1.000 & & & & & & \\
\hline DOC & $0.739^{*}$ & 1.000 & & & & & \\
\hline $\mathrm{C} 1$ & $0.842 * *$ & $0.827 * *$ & $0.912 * *$ & 1.000 & & & \\
\hline $\mathrm{C} 2$ & 0.592 & 0.590 & $0.829 * *$ & 0.547 & 1.000 & & \\
\hline C3 & $0.713^{*}$ & $0.729^{*}$ & $0.960 * *$ & $0.769 * *$ & $0.942 * *$ & 1.000 & \\
\hline
\end{tabular}

in DOC concentration induced by $\mathrm{Cu}^{2+}$ and $\mathrm{Zn}^{2+}$ treatment in the stationary phase (Fig. 2) was caused by the influence of heavy metals on biomass of $M$. aeruginosa, but not by variations in cellular secretion. The component percentage amounts calculated from their fluorescence intensities on day 18 were similar among different treatments. On day 18 , the fluorescence intensities of all four components were significantly related to the total fluorescence intensity. Therefore, similar to day 10 , the DOM composition was not affected by heavy metal addition on day 18.

Extracellular polymeric substances (EPS) are the main components of DOM released by Microcystis. ${ }^{18}$ EPS has been reported to play a role in protecting algae against heavy metal toxicity $^{37,38}$ and other chemical stresses. ${ }^{39,40}$ Humic acid-like compounds have been used to chelate heavy metals. ${ }^{30}$ Herzi et al. ${ }^{14}$ also suggested that both tryptophan-like compounds and proteins could chelate heavy metals to reduce their toxicity. Our results showed that the DOM composition produced by Microcystis was not affected by heavy metal addition, but that the concentration of each component increased when treated with heavy metal. It was deduced that all four compounds identified in the current study could be used to chelate heavy metals to reduce their toxicity toward M. aeruginosa. However, Microcystis increased DOM production in the logarithmic phase by altering cellular secretion, but high biomass was the effective measure for $M$. aeruginosa to reduce the toxicity of heavy metals in the stationary phase. Xu et al. ${ }^{18}$ indicated that two protein-like components and a humic acid-like component were significantly correlated with the cell density of $M$. aeruginosa culture in low nutrient medium and standard medium. Our results differed from theirs because heavy metal addition in the current study altered the DOM production of M. aeruginosa.

Our results demonstrated that 0.05 and $0.1 \mathrm{mg} \mathrm{L}^{-1} \mathrm{Cu}^{2+}$ improved DOM production in $M$. aeruginosa during the logarithmic phase, but $0.25 \mathrm{mg} \mathrm{L}^{-1} \mathrm{Cu}^{2+}$ reduced DOM production. In addition, $0.10-1.00 \mathrm{mg} \mathrm{L}^{-1} \mathrm{Zn}^{2+}$ stimulated DOM release from $M$. aeruginosa in different growth phases. All above concentrations of $\mathrm{Cu}^{2+}$ and $\mathrm{Zn}^{2+}$ have been detected in natural waters bodies, including Lake Taihu ${ }^{20}$ and Lake Qarun. ${ }^{41}$ Therefore, the DOC concentrations in these waters would increase due to the effects of heavy metals on DOM release by Microcystis and other phytoplankton. The increasing DOC would affect carbon and nitrogen cycles, ${ }^{42}$ the abundance and community of aquatic microorganisms, ${ }^{43}$ and the fate and transport of hazardous materials ${ }^{44,45}$ in natural waters. Therefore, the effects of heavy metals in relatively safe concentrations on aquatic ecosystems should be considered because they can alter DOM production by phytoplankton especially for Microcystis.

\section{Conclusions}

(1) During the logarithmic phase, moderate levels of $\mathrm{Cu}^{2+}(0.05$ and $\left.0.10 \mathrm{mg} \mathrm{L}^{-1}\right)$ and high levels of $\mathrm{Zn}^{2+}\left(1.00 \mathrm{mg} \mathrm{L}^{-1}\right)$ stimulated DOC production of M. aeruginosa. In the stationary phase, moderate levels of $\mathrm{Zn}^{2+}\left(0.10-0.50 \mathrm{mg} \mathrm{L} \mathrm{L}^{-1}\right)$ stimulated DOC production, but high levels of $\mathrm{Cu}^{2+}\left(0.10 \mathrm{mg} \mathrm{L}^{-1}\right)$ decreased DOC concentration compared with the control.

(2) Four components were identified from fluorescence spectra by EEM-PARAFAC, consisting of two humic-like components (C1 and $\mathrm{C} 3$ ) and two protein-like components (C2 and C4). The fluorescence intensities of all four components in the DOM were improved on day 10 when treated with moderate levels of $\mathrm{Cu}^{2+}\left(0.05\right.$ and $\left.0.10 \mathrm{mg} \mathrm{L}^{-1}\right)$, but the fluorescence intensities of $\mathrm{C} 1, \mathrm{C} 3$, and $\mathrm{C} 4$ in the DOM on day 18 were improved when treated with moderate levels of $\mathrm{Zn}^{2+}(0.10-$ $\left.0.50 \mathrm{mg} \mathrm{L}^{-1}\right)$.

(3) The DOM composition produced by Microcystis was not affected by heavy metal addition. Microcystis increased DOM production in the logarithmic phase by altering cellular secretion, but high biomass was the effective measure for M. aeruginosa to reduce the toxicity of $\mathrm{Cu}$ and $\mathrm{Zn}$ in the stationary phase.

\section{Acknowledgements}

This study was sponsored by the National Natural Science Foundation of China (Grant 51409216, 51508466) and the Special Funds Projects for Control Water Pollution in Lake Taihu, Section Ten (Grant JSZC-G2016-198).

\section{References}

$1 \mathrm{~J}$. W. Moore and S. Ramamoorthy, Organic Chemicals in Natural Waters Applied Monitoring \& Impact Assessment, Springer Series on Environmental Management, 2012. 
2 A. Altındağ and S. Yiğit, Chemosphere, 2005, 60, 552-556.

3 R. Dallinger, F. Prosi, H. Segner and H. Back, Oecologia, 1987, 73, 91-98.

4 E. Pinto, T. Sigaud-kutner, M. A. Leitao, O. K. Okamoto, D. Morse and P. Colepicolo, J. Phycol., 2003, 39, 1008-1018.

5 K. D. Joehnk, J. E. F. Huisman, J. Sharples, B. E. N. Sommeijer, P. M. Visser and J. M. Stroom, Summer heatwaves promote blooms of harmful cyanobacteria, Global Change Biol., 2008, 14, 495-512.

6 H. W. Paerl, R. S. Fulton, P. H. Moisander and J. Dyble, Sci. World J., 2001, 1, 76-113.

7 A. de Kluijver, J. L. Yu, M. Houtekamer, J. J. Middelburg and Z. W. Liu, Limnol. Oceanogr., 2012, 57, 1245-1254.

8 T. B. Bittar, A. A. Vieira, A. Stubbins and K. Mopper, Limnol. Oceanogr., 2015, 60, 1172-1194.

9 I. Sundh, Appl. Environ. Microbiol., 1992, 58, 2938-2947.

10 L. Ye, X. Shi, X. Wu and F. Kong, J. Limnol., 2012, 71, 67-71.

11 Z. Yang and F. Kong, Chin. J. Oceanol. Limnol., 2013, 31, 796802.

12 M. Li, W. Zhu, L. Gao and L. Lu, J. Appl. Phycol., 2013, 25, 1023-1030.

13 X. D. Bi, S. L. Zhang, W. Dai, K. Z. Xing and F. Yang, Water Sci. Technol., 2013, 67, 803-809.

14 F. Herzi, N. Jean, A. Sakka Hlaili and S. Mounier, J. Phycol., 2014, 50, 665-674.

15 Y. Yamashita, R. Jaffé, N. Maie and E. Tanoue, Limnol. Oceanogr., 2008, 53, 1900-1908.

16 H. Xu, H. Jiang, G. Yu and L. Yang, Chemosphere, 2014, 117, 815-822.

17 H. Xu, L. Guo and H. Jiang, Chemosphere, 2016, 145, 551559.

18 H. Xu, H. Cai, G. Yu and H. Jiang, Water Res., 2013, 47, 20052014.

19 L. García-Villada, M. Rico, M. Altamirano, L. SánchezMartín, V. López-Rodas and E. Costas, Water Res., 2004, 38, 2207-2213.

20 Y. Tao, Z. Yuan, M. Wei and H. Xiaona, Environ. Monit. Assess., 2012, 184, 4367-4382.

21 R. Hänsch and R. R. Mendel, Curr. Opin. Plant Biol., 2009, 12, 259-266.

22 S. P. Gouvêa, G. L. Boyer and M. R. Twiss, Harmful Algae, 2008, 7, 194-205.

23 C. A. Stedmon and R. Bro, Limnol. Oceanogr.: Methods, 2008, 6, 572-579.
24 K. P. Tsai, Ecotoxicol. Environ. Saf., 2015, 120, 428-435.

25 Z. X. Wu, N. Q. Gan, Q. Huang and L. R. Song, Environ. Pollut., 2007, 147, 324-330.

26 C. Deng, X. Pan, S. Wang and D. Zhang, Biol. Trace Elem. Res., 2014, 160, 268-275.

27 Y. Polyak, T. Zaytseva and N. Medvedeva, Water, Air, Soil Pollut., 2013, 224, 1-14.

28 C. J. Williams, Y. Yamashita, H. F. Wilson, R. Jaffé and M. A. Xenopoulos, Limnol. Oceanogr., 2010, 55, 1159-1171.

29 W. Chen, P. Westerhoff, J. A. Leenheer and K. Booksh, Environ. Sci. Technol., 2003, 37, 5701-5710.

30 A. M. McIntyre and C. Guéguen, Chemosphere, 2013, 90, 620626.

31 Y. Wang, D. Zhang, Z. Shen, C. Feng and J. Chen, PLoS One, 2013, 8, e76633.

32 J. B. Fellman, E. Hood and R. G. Spencer, Limnol. Oceanogr., 2010, 55, 2452-2462.

33 F. Qu, H. Liang, Z. Wang, H. Wang, H. Yu and G. Li, Water Res., 2012, 46, 1490-1500.

34 J. Hur, B. M. Lee and K. H. Shin, Chemosphere, 2014, 111, 450-457.

35 S. Aoki, S. Ohara, K. Kimura, H. Mizuguchi, Y. Fuse and E. Yamada, Anal. Sci., 2008, 24, 389-394.

36 C. Yang, Y. Liu, Y. Zhu and Y. Zhang, Mar. Pollut. Bull., 2016, 104, 113-120.

37 L. R. Andrade, R. N. Leal, M. Noseda, M. E. R. Duarte, M. S. Pereira, P. A. Mourão, M. Farina and G. M. Amado Filho, Mar. Pollut. Bull., 2010, 60, 1482-1488.

38 S. Ozturk, B. Aslim and Z. Suludere, Bioresour. Technol., 2010, 101, 9742-9748.

39 L. Gao, X. Pan, D. Zhang, S. Mu, D. J. Lee and U. Halik, Water Res., 2015, 69, 51-58.

40 H. Yoshimura, T. Kotake, T. Aohara, Y. Tsumuraya, M. Ikeuchi and M. Ohmori, J. Appl. Phycol., 2012, 24, 237243.

41 S. A. Mansour and M. M. Sidky, Food Chem., 2002, 78, 15-22.

42 C. L. Goodale, J. D. Aber, P. M. Vitousek and W. H. McDowell, Ecosystems, 2005, 8, 334-337.

43 K. E. Judd, B. C. Crump and G. W. Kling, Ecology, 2006, 87, 2068-2079.

44 C. Gourlay, M. H. Tusseau-Vuillemin, J. M. Mouchel and J. Garric, Ecotoxicol. Environ. Saf., 2005, 61, 74-82.

45 K. Kalbitz and R. Wennrich, Sci. Total Environ., 1998, 209, 27-39. 